\title{
“The Future Is Not What It Used To Be"
}

James J. Duderstadt, President

The University of Michigan

Honors Convocation Address

March 24, 1996 
As many of you know, this will be the last time I will have the opportunity to participate in the Honors Convocation as president of the University. In this last

appearance, I felt quite honored to be asked by your student honors committee to be the speaker. I have accepted this as both an honor and a challenge, to make my remarks profound...and profoundly brief.

You will have to pardon a lame-duck if I begin by traveling far back in to the prehistoric past, to a time when I was in your position as a student. After a brief interlude, I promise to return to the present and then move ahead to speculate a bit about the future--your future.

Some Personal Experiences

My college years were during the early 1960s--which seems like an eternity ago. That was still a time of optimism in America. The glow of Camelot of the Kennedy administration still lingered with us. There were great causes to take up such as world peace, the conquest of space, the civil rights movement. Indeed, Martin Luther King, Jr., himself was the commencement speaker at my graduation.

My Class of 1964 graduated with a feeling of boundless confidence in ourselves and in our country. We each had mighty visions of changing the world. In fact, I chose to go into the exotic field of nuclear engineering because I felt that we could "make the deserts bloom" by creating a limitless source of energy for mankind. My first job after college was out in the deserts of New Mexico at Los Alamos, developing nuclear rocket engines that we expected soon to power the first manned mission to Mars and beyond and which would be used to colonize the solar system.

Like many generations of Americans before us, the Class of 1964 took for granted our nation's leadership, our motives for good, the virtues of science and technology. We believed that we would live better than our parents and that our 
children would have a life even better than ours, that old fashioned virtues and hard work would guarantee our own personal futures and our nation's future.

But there were already clouds gathering on the horizon. Even during my senior year it was suggested that things would not be quite so simple, that dramatic changes were coming. John F. Kennedy was assassinated during that fall. The Cold War had begun to heat up with the Cuban Missile Crisis. A few people were talking about a distant war in a place called Viet Nam. Civil rights protests were challenging racism. The free speech movement at Berkeley was revealing a new spirit of student anger and activism on the campuses.

But even with these warning signs, we were not prepared for the dramatic crises and confrontations, the great changes Americans and their institutions would face in the years immediately following our graduation: the war in Viet Nam that so profoundly affected all of our lives, both those who served and those who protested; the eruption of assassination and terrorism, which robbed us of our heros; the racial turmoil that tore apart our cities; the social turbulance and seeming disintegration of national consensus and confidence; the emergence of the drug culture, as more people turned on and tuned out; Watergate and the crisis in confidence in our leaders.

Americans experienced a sense of shock as our nation began to encounter limits for the first time, as the environmental movement exposed the downside of technological progress, as foreign competition challenged our enterprise, and as our economic and political preeminence was challenged by new centers of power in Asia, Europe, and the Middle East.

In a sense, during the decade following my graduation, America lost its innocence. It lost its sense of optimism. In many ways, my class may have represented the last generation of Americans to be truly optimistic about the future, to welcome its challenges and to feel equal to them. I can't say whether or not my own choice of a career would have been different if I could have foreseen 
the future. But perhaps it is useful this afternoon to engage in some futuring, to speculate a bit about the world you will be entering.

\section{Possible Futures}

The French poet, Paul Valery, once said, "The trouble with our times is that the future is not what it used to be." If my experience is any guide, your future will be a time of greater change and transformation than any experienced before in our nation's history. You are graduating at a truly extraordinary time. Think about it for a moment. You were born and educated in the 20th century. Indeed, most of you are children of the '60s generation--my generation and that's a frightening thought! Yet, you will be spending the majority of your life in the next century, in the 2lst century. And while it is always risky to speculate about the future, three themes of the next century seem clear:

The Challenge of Change

We are living in the most remarkable of times. Who would have predicted a few years ago:

- the collapse of communism and the end of the Cold War

- the redefinition of the world economic order

- the direct manipulation of the human gene to cure disease

- an abrupt change from a Republican president...and a

Democratic congress...to just the opposite...the Newtonian revolution

- the corporate downsizing phenomena, in which over $40 \mathrm{M}$ people have lost their jobs over the past five years

- the Internet phenomena, linking 25 million people 
worldwide

- digital convergence, in which communications and computer companies merge with the entertainment industry.

Yet all of these events have happened, and the pace of change continues to accelerate.

Indeed, many believe that we are going through a period of change in our civilization just as profound as that which occurred in earlier times such as the Renaissance and the Industrial Revolution--except that while these earlier transformations took centuries to occur, the transformations characterizing our times will occur in a decade or less!

I used to portray the 1990s as the countdown toward a new millennium, as we found ourselves swept toward a new century by these incredible forces of change. But the events of the past several years suggest that the twenty-first century is already upon us, a decade early. We live in a time of breathtaking change, at a pace that continues to accelerate even as I speak.

This last point is very important, for today we are seeing a dramatic shift in the fundamental structure, nature, and perspective of our society. We are evolving rapidly into a society in which the key strategic resource necessary for prosperity and social well-being has become knowledge itself. In this world knowledge will play the same role that in the past was played by natural resources or geographic location or labor pools. Put another way, while forces such as land, guns, and money drove the past, ideas will be the driving force of the twenty-first century.

The "age of knowledge" in which we now find ourselves is accompanied by a fundamental transformation that is reshaping every product, every service, and every job throughout our nation and the world. 
Several weeks ago the New York Times ran a week-long series about the human costs of the corporate effort to boost productivity and profits through downsizing. Since 1979, they estimate that more than 43 million jobs have been eliminated in America. A recent UM study found that among the collegeeducated over 50, the rate of layoffs doubled from the 1980s to the 1990s. And although most find new jobs, these are usually at lower pay. As the NYT pus it:

“The lion's share of raises and bonuses are now channeled to those judged most talented and diligent. This new standard of "pay for performance" has made a growing divide among incomes a hallmark of the layoff era. In essence, a new notion of growth and job creation has emerged in which, rather than an expanding economy benefiting all, only the stellar performers-or those providentially in the right careers--come out ahead.

The America of the 20th century that I have known was a nation characterized by a rather homogeneous, domestic, industrialized society. But that is an America of the past. You will inherit a far different nation, a highly pluralistic, knowledge-intensive, world-nation that will be America of the 2lst century.

These themes of your future--the changing nature of the American population, our increasing interdependence with other nations and other peoples, and the shift to a knowledge-intensive, post-industrial society--are actually not themes of the future, but rather themes of today. In a sense, I have simply been reading the handwriting on the wall.

The Challenge of Change

Indeed, change itself might be regarded as the most important theme in characterizing your future that I can predict with some certainty. It is clear that the future will never again be what it used to be! 
New ideas and concepts are exploding forth at ever-increasing rates. Indeed, in many fields the knowledge base is doubling every few years. The knowledge you have mastered as undergraduates is becoming obsolete even as you are graduating. As the pace of the creation of new knowledge accelerates, it seems clear that we are entering a period in which permanence and stability have become less valued than flexibility and creativity--a period in which the only certainty will be the presence of continual change; and the capacity to relish, stimulate, and manage change will be one of the most critical abilities of all.

Here we face a particular challenge, however, since most of us have been trained from an historical perspective to think in terms of change as a linear, causal, and rational process. We have been taught that by looking to the past, we can simply extrapolate linearly to predict the future.

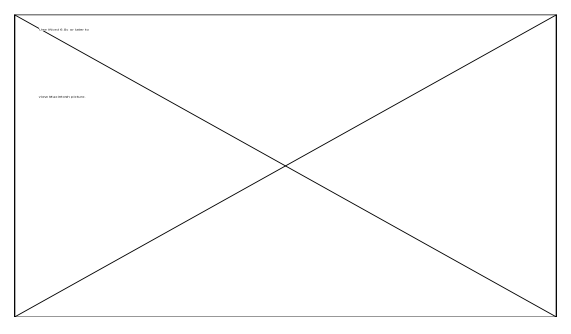

Of course, the scientist has a much different view of change, a view that is somewhat more disturbing. The scientist notes that most change in our natural world does not occur linearly with time, but rather exponentially, at everincreasing rates.

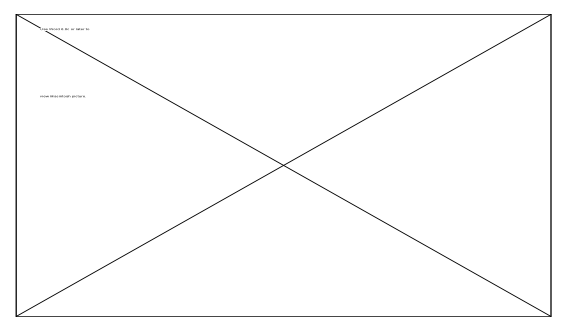


From this view the challenges that face us, challenges such as the growth of the world's population, or the consumption of our natural resources, or the pollution of our planet, are growing ever more serious at exponential rates.

Enter the economist who says, "Not to worry." Sooner or later every exponential phenomenon eventually reaches a limit, a saturation, as a law of diminishing returns sets in.

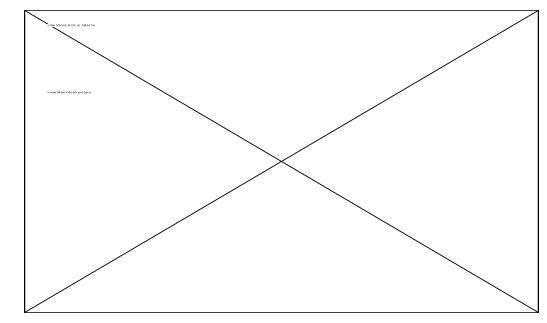

Sooner or later we run out of the necessary resources to sustain exponential growth, and the process of change slows to a halt. The bacterial colony on the petri dish runs out of nutrient. World population will run out of land surface-perhaps when, in the year 2500, there are forty trillion people on earth with only one square yard per person!

$\mathrm{Ah}$, but we have learned in recent years that the world really doesn't work like this either! Our reductionist, atomic, predictable perspective of the world, the rational, scientific view that so dominated the 20th Century, has itself been challenged. We have learned that even the simplest systems in nature tend to behave in a far more complex and unpredictable fashion. They follow a change process known in today's popular lexicon as "chaos", or "complex adaptive systems"...or perhaps even more descriptive, "swarm systems". While the early stages of change may be linear, exponential, or perhaps even saturating, at later stages change frequently occurs in a far more dramatic and unpredictable way. 


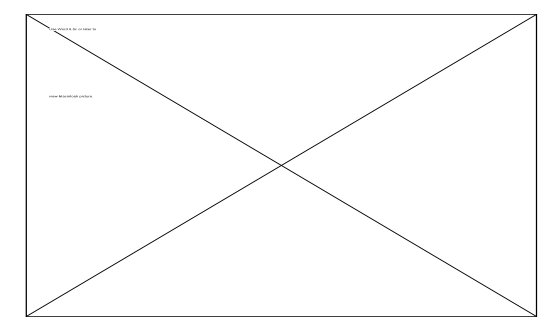

In this view of the world, systems become unstable and undergo dramatic and often chaotic change to create new levels of order and complexity. For example, witness the complex evolution of the clouds in the sky, or the complexity of flowing water, or the extraordinary complexity and diversity of living creatures...or the Newtonian revolution in Congress in 1995...

There are several particular features of this modern view of change that have major implications for the world in which we live:

1. First, from this modern view, change is not simple and gradual and linear. Rather, it is characterized by non-linearities that lead to complex behavior- frequently to dramatic rather than gradual change--to revolution rather than evolution.

2. But that's not all. Change is also not predictable and deterministic but rather random and stochastic in nature. The real world works in sharp contrast to the deterministic views of classical science, or Newton or such modern determinists as Freud or Marx or Skinner. That's the bad news. Now for the good news!

3. Chaotic change depends far more sensitively on small disturbances than we had ever thought possible. To mathematicians, chaotic systems are termed "ill-posed." But the popular press has a more picturesque term known as the "butterfly effect." This term arises from the suggestion that even the disturbance in the air caused by a butterfly's wings could cause major changes in the weather half-way around the globe because of the 
chaotic nature of weather patterns. Translated into more human terms, dramatic change is frequently triggered by a few extraordinary people with extraordinary ideas, or by the young or newly initiated, people who haven't had the time yet to become trapped in the same ruts as the more experienced of us. More specifically, change is frequently triggered by people exactly like you here before me today!

To put it more bluntly, if this modern view of change is right, each of you will have a truly remarkable chance to change the world! But you will also be faced with some unusual challenges.

Implications for Your College Education

If indeed your future will be one characterized by rapid, unpredictable, and dramatic change, then it becomes apparent that your capacity for continual renewal and personal development will become increasingly important. Has your education here at Michigan helped you to value, welcome, and control change?

I hope so. While most of you have probably looked at your college education as a preparation for a career--as scientists or engineers, as doctors, lawyers, or teachers, or even investment bankers, I suspect that was not the real purpose of your education at Michigan. The eminent philsopher Alfred North Whitehead, once stated that the purpose of a college education was "to learn the art of life." Well, in a very real sense, that is what you should have been learning at Michigan. You should have sought--and must continue to seek--a spirit of liberal learning, a spirit that will enrich your lives and through you, the lives of your families, friends, and colleagues.

But I suspect that it may be dawning on many of you this afternoon that perhaps you are not learning as much about the "art of life" at Michigan as you might have wished. (I certainly didn't when I was an undergraduate.) But not to 
worry. Your college education was intended only as a stepping stone to a process of lifelong education. Indeed, most college graduates of your generation will find themselves changing careers several times during their lives. Hence, you will find yourselves continuing to learn--and re-learn--and re-learn yet again through self-study and a return to school on occasion as you adapt to a world of change.

\section{A Future of Hope}

The modern view of change suggests that the future is indeed not what it used to be--or at least as it has been traditionally portrayed, as a time of gradual, predictable change, rigidly moored to the past. Rather, my crystal ball suggests a future characterized by rapid, unpredictable, and frequently dramatic change in the nature of our people--in our bonds to other socieities--in what we do. It will be a future of great challenge and responsibility.

Indeed, as you stand today on the threshold of a new century, it seems clear that your generation will face problems and challenges of a magnitude that would have been incomprehensible in earlier times. Further, your years following graduation will be a time of less security, less stability, and more unpredictability than mine. But you will also face a future of extraordinary opportunity and excitement. For, as the philosopher Whitehead has noted, "The great ages have been unstable ages!"

Emerson once noted that the wisest counsel of all to the young was to "always do what you are afraid to do." The truth is that adapting to change and challenge is what keeps our species evolving. We should relish change, welcome it, seek it out--not for its own sake, but for the challenge it brings and the possibility for progress. We should approach life as a true adventure of opportunity and risk. We are made for risk. We thrive on it. 
I guess I tend to be an incurable optimist. I believe that we can be masters of our fate, that we can seize control of the forces around us--most of all ourselves-and bring progress to the world. In fact, I even think that each individual has the possibility to change the world. Just remember the "butterfly effect." You can change the world with the beat of your own wings.

There is an old saying that "the best way to predict the future is to invent it!" That is the real challenge before you: to go out into that exciting world full of challenge and opportunity and to invent the future! Indeed, it is your challenge to make certain that the future will not be what it used to be! 